\title{
Dynamic Slip Transfer from the Denali to Totschunda Faults, Alaska: Testing Theory for Fault Branching
}

\author{
by Harsha S. Bhat, Renata Dmowska, James R. Rice, and Nobuki Kame
}

\begin{abstract}
We analyze the observed dynamic slip transfer from the Denali to Totschunda faults during the $M_{\mathrm{w}} 7.93$ November 2002 Denali fault earthquake, Alaska. This study adopts the theory and methodology of Poliakov et al. (2002) and Kame et al. (2003), in which it was shown that the propensity of the rupture path to follow a fault branch is determined by the preexisting stress state, branch angle, and incoming rupture velocity at the branch location. Here we check that theory on the DenaliTotschunda rupture process using 2D numerical simulations of processes in the vicinity of the branch junction. The maximum compression direction with respect to the strike of the Denali fault near the junction has been estimated to range from approximately $73^{\circ}$ to $80^{\circ}$. We use the values of $70^{\circ}$ and $80^{\circ}$ in our numerical simulations. The rupture velocity at branching is not well constrained but has been estimated to average about $0.8 c_{s}$ throughout the event. We use $0.6 c_{s}, 0.8 c_{s}, 0.9 c_{s}$, and even $1.4 c_{s}$ as parameters in our simulations. We simulate slip transfer by a $2 \mathrm{D}$ elastodynamic boundary integral equation model of mode II slip-weakening rupture with self-chosen path along the branched fault system. All our simulations except for $70^{\circ}$ and $0.9 c_{s}$ predict that the rupture path branches off along the Totschunda fault without continuation along the Denali fault. In that exceptional case there is also continuation of rupture along the Denali fault at a speed slower than that along the Totschunda fault and with smaller slip.
\end{abstract}

\section{Introduction}

A $M_{\mathrm{w}} 7.9$ earthquake struck central Alaska on 3 November 2002. The Denali fault earthquake (DFE) occurred along the Denali fault system and ruptured a total length of approximately $350 \mathrm{~km}$. The last segment of rupture was along the Totschunda fault, which branches off from the Denali fault, with $68 \mathrm{~km}$ of observed surface rupture (Peter Haeussler, U.S. Geological Survey [USGS], Anchorage; personal comm., 2002) (see Figure 1a [epicenter: star in center left of the figure]). Beyond the branching location no surface rupture was visible on the Denali fault for at least $25 \mathrm{~km}$ (P. Haeussler, USGS; personal comm., 2002).

Beyond the Denali-Totschunda branching location the aftershocks of the $M_{\mathrm{w}} 7.9$ event occurred predominantly along the Totschunda fault segment (Fig. 1b) (EberhartPhillips et al., 2003). Together with the lack of surface rupture along the continuation of the Denali fault, this indicates that after branching the rupture progressed exclusively along the Totschunda fault.

\section{Summary of Theory for Fault Branching}

Following the concepts introduced by Poliakov et al. (2002) on factors governing fault branching, Kame et al.
(2003) performed an extensive set of numerical simulations of branching. Those were done in the context of a $2 \mathrm{D}$, mode II, rupture model with a slip-weakening friction coefficient, with strength during slip-weakening proportional to the instantaneous local normal stress. They involved a range of branching fault angles $(\varphi)$ with the primary fault, rupture velocities $\left(v_{r}\right)$ approaching the branching location, and maximum horizontal prestress inclinations $(\Psi)$ with the main fault. See Figures 2-4 for their results which are most relevant for the present discussion; all results are shown for right-lateral rupture.

The results can be summarized as follows. For a given rupture velocity the most vulnerable branch orientations change from those on the compressional side $(\varphi>0)$ to those on the extensional side $(\varphi<0)$ with increasing orientation of the maximum horizontal stress with the main fault (as partly illustrated in Figs. 2 and 3). The tendency of the rupture path to proceed exclusively on the branch also increases (and becomes increasingly independent of rupture velocity) as one approaches the limits of maximum stress inclinations with respect to the main fault $\left(0^{\circ}\right.$ or $90^{\circ}$ for exclusive propagation on compressional or extensional branches, respectively). With increasing rupture velocity 
(a)

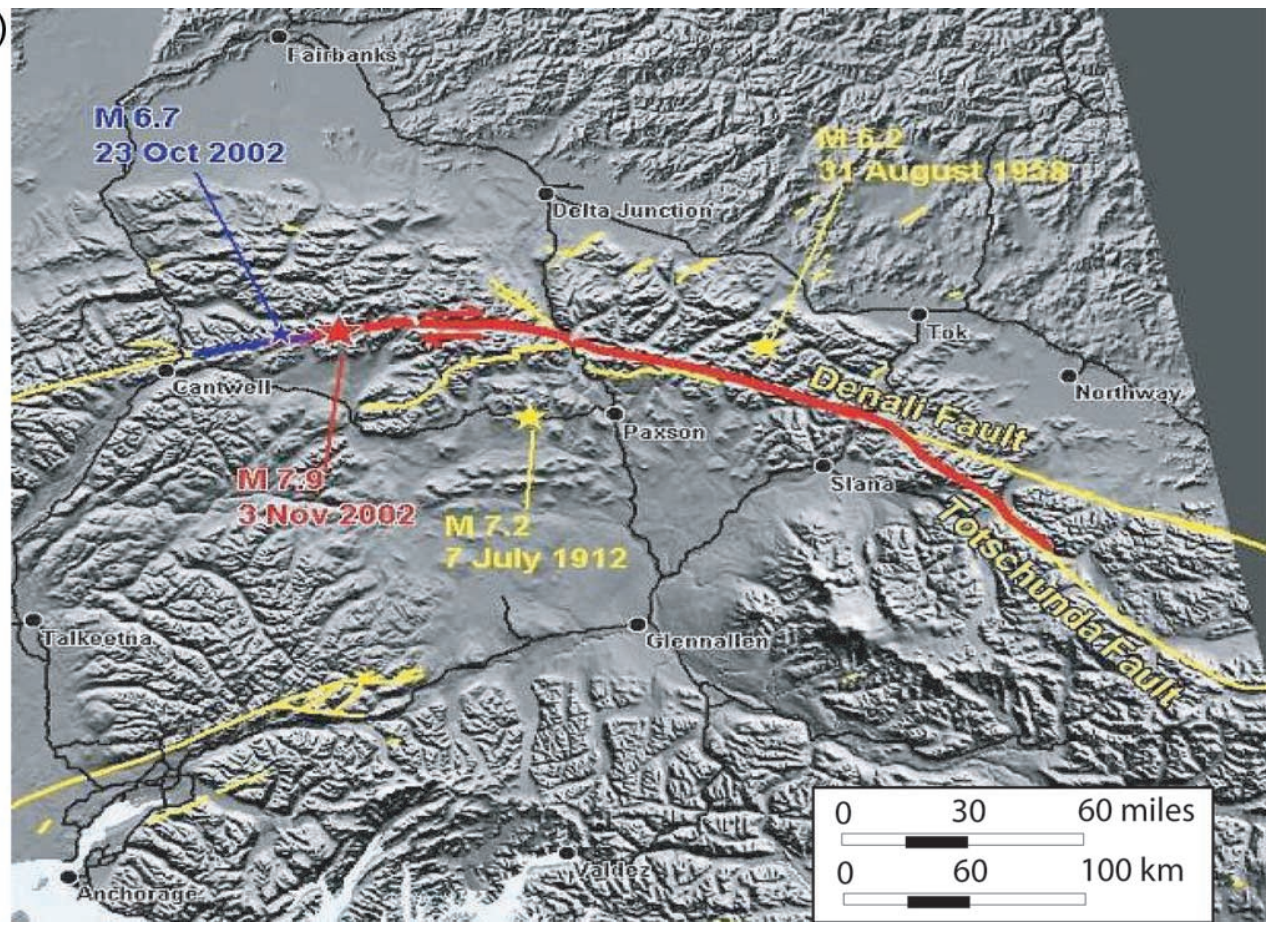

(b)

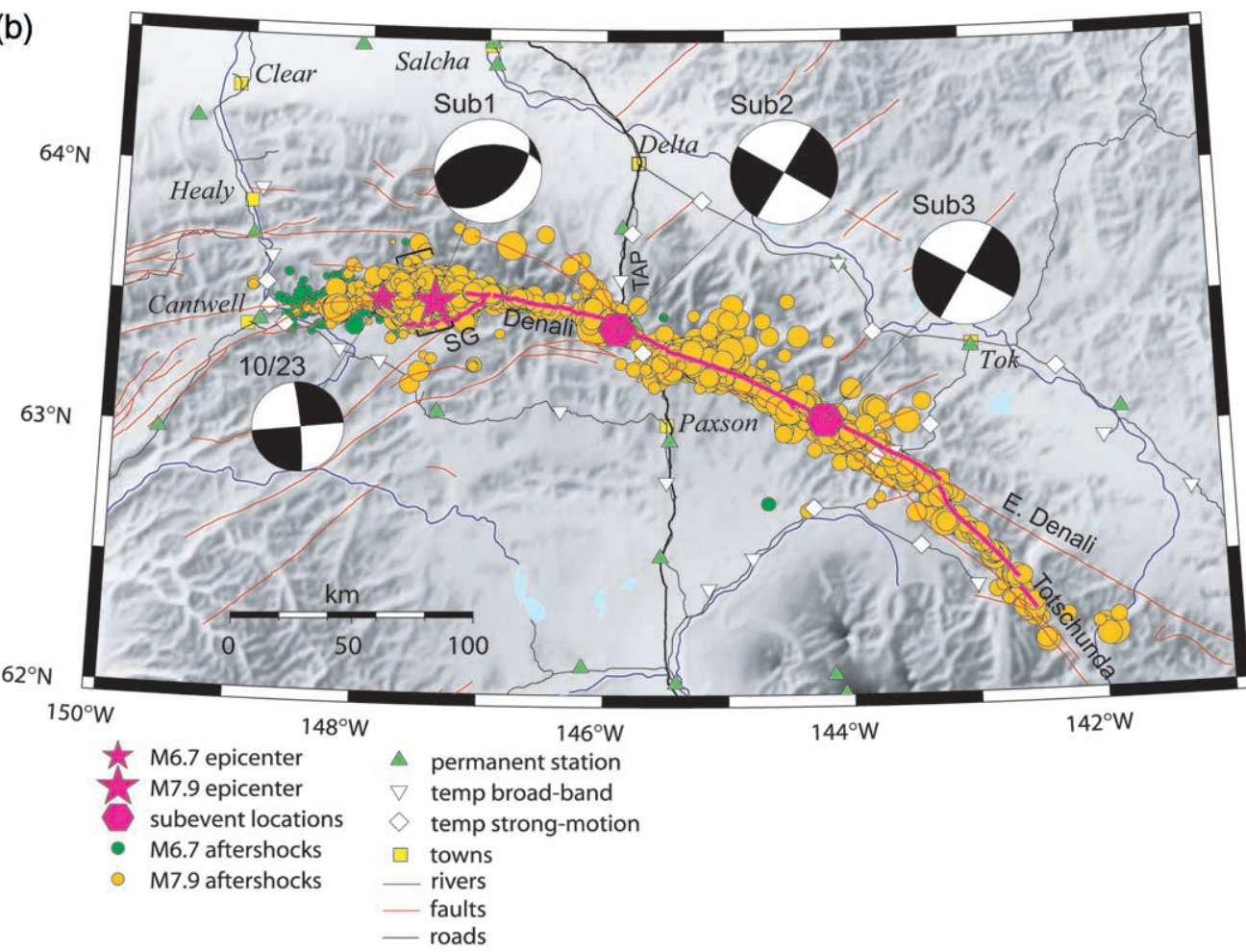

Figure 1. (a) Rupture path, solid line, of the $M_{\mathrm{w}} 7.9$ Denali fault earthquake. A star toward the left of center of the figure marks the epicenter of the 3 November 2002 event (figure courtesy of Alaska Division of Geological and Geophysical Surveys). (b) Aftershocks of the $M_{\mathrm{w}} 7.9$ event, from Eberhart-Phillips et al. (2003), also showing three subevents during the rupture. 


$$
\Psi=56^{0} ; v_{r}=0.8 c_{S}
$$
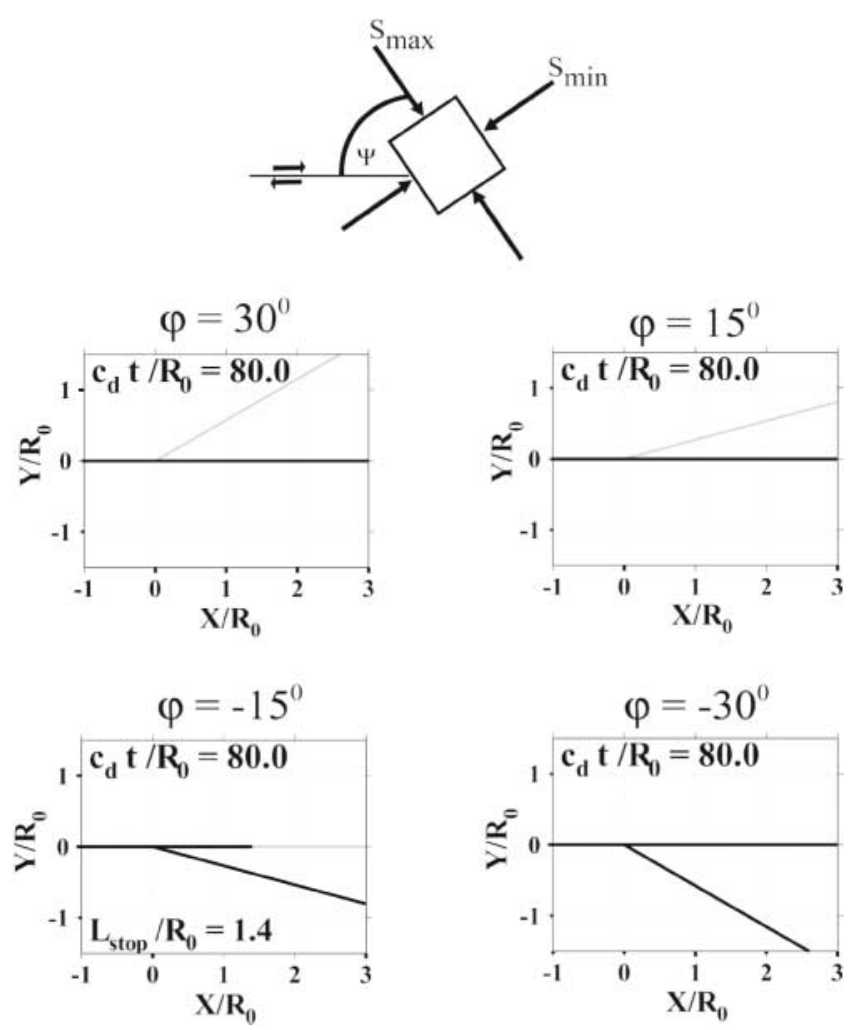

Figure 2. Results of 2D numerical simulations from Kame et al. (2003) showing the influence of branching angle $(\varphi)$ on a right-laterally propagating rupture at a velocity $\left(v_{r}\right)$ of $0.8 c_{s}$ near the branching location. The orientation angle $\Psi$ of the principal maximum stress with respect to the main fault is $56^{\circ}$. The solid black line shows the path of the rupture; fault regions are shown in gray; $c_{s}$ is the shear-wave speed of the medium.

(keeping $\Psi$ constant) the stress shadow effect of one fault on another, which is important for small branching angles, decreases; this makes the rupture path lie less exclusively either along the main fault or along the branched one (Fig. 4). The parameter $L_{\text {stop }} / R_{0}$ in the figures refers to the distance, $L_{\text {stop }}$, beyond the branch junction at which propagation has stopped on either the branch or the main fault. $L_{\text {stop }}$ is normalized by $R_{0}$, which is the length that the slipweakening zone would occupy along the main fault in low speed propagation (Kame et al., 2003).

\section{Determination of Parameters Influencing Branching for the Denali Fault Earthquake}

\section{Maximum Principal Stress Direction ( $\Psi$ )}

Nakamura et al. (1980) estimated the late Quaternary tectonic stress trajectories in the Aleutians and Alaska, using geologic indicators along continental Alaska. Their results show averaged directions of maximum horizontal compression. The principal stress direction near to the DenaliTotschunda branching region is estimated from their results as approximately $75^{\circ}$ with respect to the main fault. Estabrook and Jacob (1991) later provided a map of maximum horizontal compression-determined stress trajectories from a variety of sources, including seismic focal mechanisms, volcanic, geologic fault, and borehole breakout data, for Alaska, the Aleutians, and the Bering Sea. This was based on the results of Nakamura et al. (1980) and Estabrook et al. (1988). The principal stress direction nearest to the Denali-Totschunda branching region was again reported to be at approximately $75^{\circ}$ with respect to the strike of the Denali fault just before branching.

Azimuths of maximum and minimum horizontal compression, obtained by using stress-tensor inversion from focal mechanisms, were determined along different fault systems in central Alaska by Ratchkovski and Hansen (2002). All their regions were on the order of 100 to $400 \mathrm{~km}$ west of the branching location, and most also to the north. The principal stress direction nearest to the Denali-Totschunda branching region was found to be approximately $73^{\circ}$ (by extrapolating results from closest locations) with respect to the strike of the Denali fault just before branching.

Based on the more recent focal mechanism inversions of Ratchkovski (2003) it can be seen that as one traverses along the Denali fault eastward, from the epicenter, the direction of principal maximum stress, before the earthquake, rotates slightly in a clockwise sense from R1 to R2 and counterclockwise from R2 to R3 (Fig. 5). The direction of principal maximum compressive stress close to the DenaliTotschunda branching location was therefore inclined at about $80^{\circ}$ with respect to the Denali fault prior to the DFE.

We choose two values of $\Psi, 70^{\circ}$ and $80^{\circ}$, to cover the range of observations. The latter better represents measurements near the branching junction; the former is an approximate lower bound based on regional stress studies. Based on the results of Kame et al. (2003), $\Psi=70^{\circ}$ is a conservative estimate for our simulations because, as it was noted earlier, the likelihood of the rupture taking the branch exclusively increases with increasing $\Psi$ and becomes increasingly independent of the rupture velocity when approaching the branching location. We will show that the rupture path is predicted to be captured exclusively by the branch in nearly all cases studied when $\Psi=70^{\circ}$ and in all cases when $\Psi=80^{\circ}$.

\section{Rupture Velocity $\left(v_{r}\right)$}

The average rupture velocity during the DFE seems to be about $80 \%$ of the shear-wave speed (Kikuchi and Yamanaka, 2002), although the velocity as the branch was approached is not yet constrained very well. Inversion of strong motion records by Eberhart-Phillips et al. (2003) revealed three subevents (Fig. 1b) during the DFE with the second and the third subevent occurring at about $125 \mathrm{~km}$ and $50 \mathrm{~km}$ 


$$
v_{r}=0.8 c_{s} ; \varphi=-15^{0}
$$
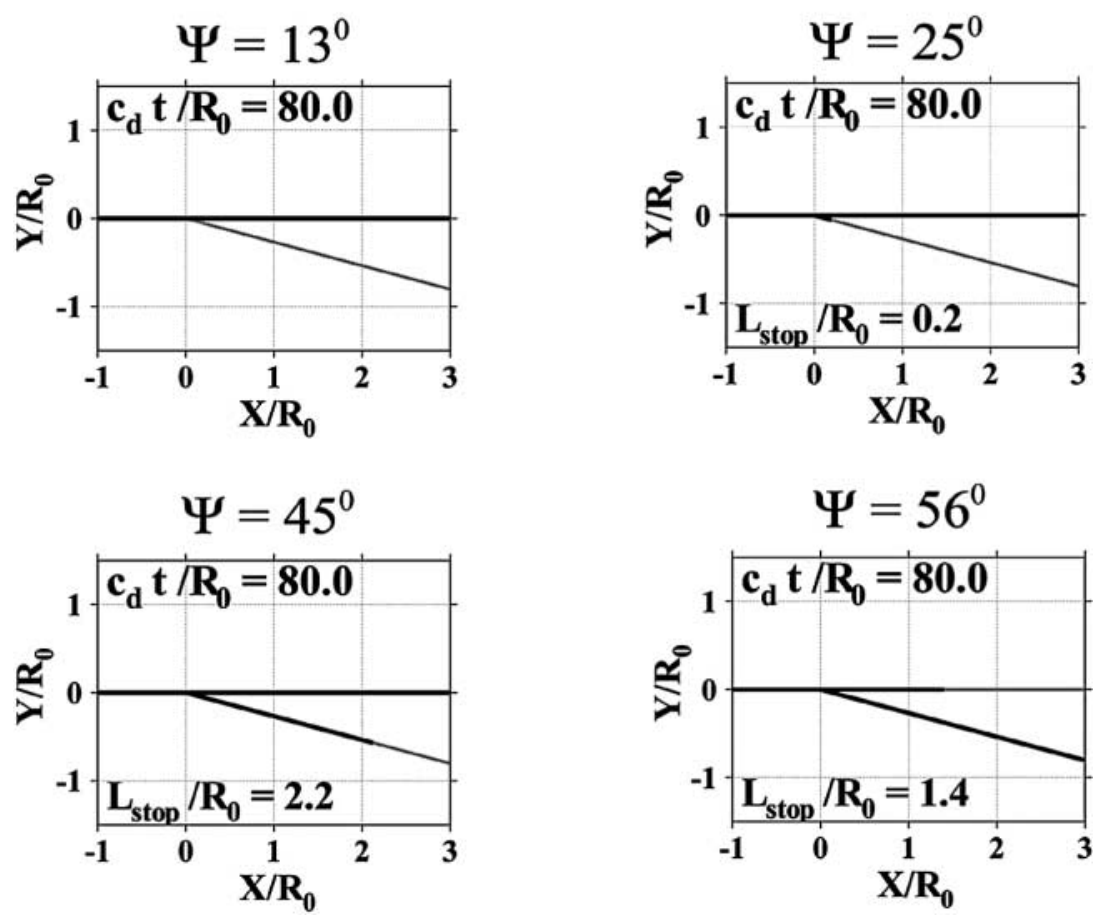

$$
\Psi=56^{0} ; \varphi=-15^{0}
$$
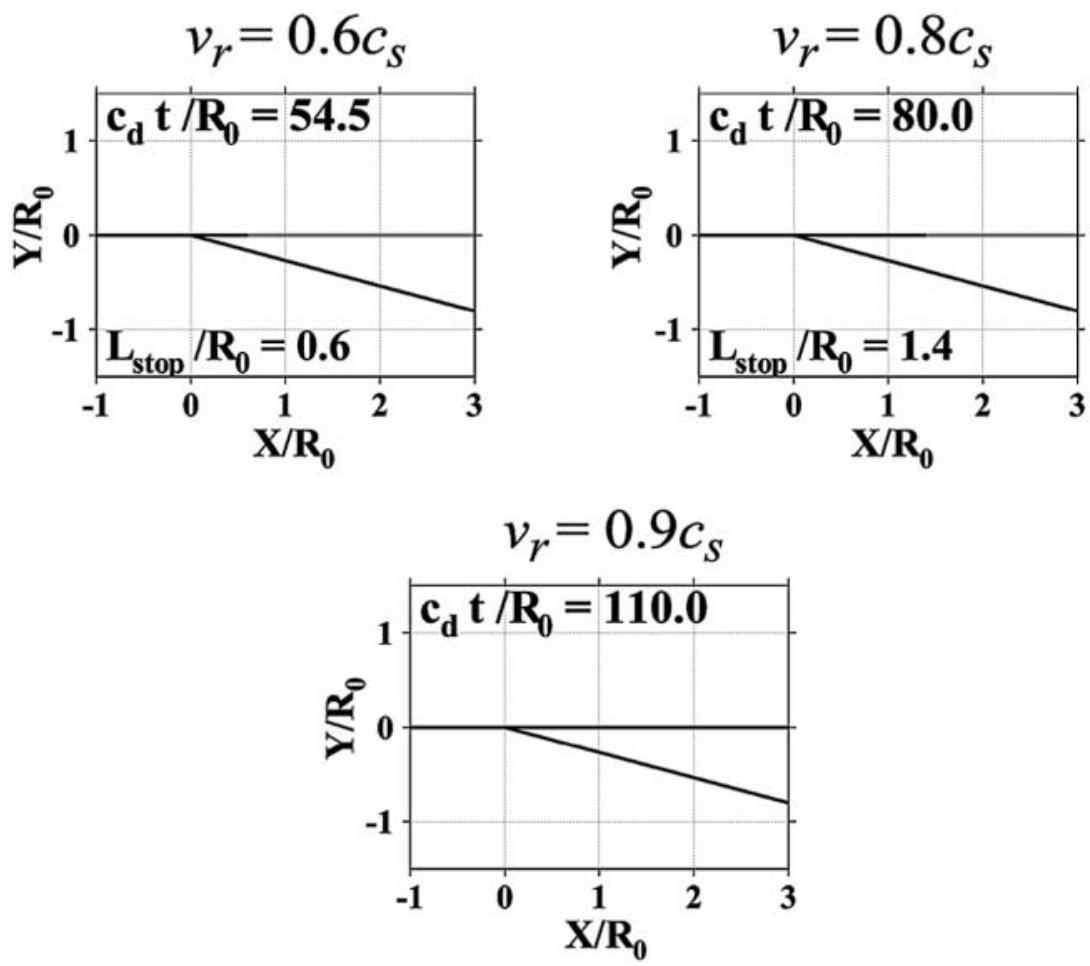

Figure 3. Results of 2D numerical simulations from Kame et al. (2003) showing the influence of the orientation of the principal maximum stress with respect to the main fault $(\Psi)$ on a right-laterally propagating rupture at a velocity $\left(v_{r}\right)$ of $0.8 c_{s}$ near the branching location. The fault geometry is fixed with the branching angle $\varphi=-15^{\circ}$.
Figure 4. Results of 2D numerical simulations from Kame et al. (2003) showing the influence of the rupture velocity at the branching location $\left(v_{r}\right)$ on a right-laterally propagating rupture approaching a branched fault segment at $\varphi=-15^{\circ}$. The orientation of the principal maximum stress with respect to the main fault $(\Psi)$ is $56^{\circ}$. The solid line shows the path of the rupture; $c_{s}$ is the shear-wave speed of the medium. 


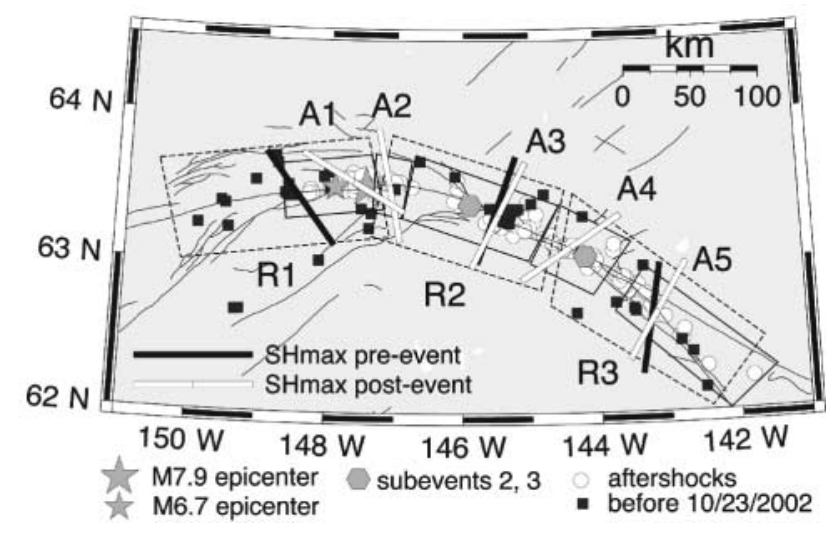

Figure 5. Maximum principal stress orientations prior to the 2002 Denali fault earthquake sequence (black bars) and for the 2002 Denali fault earthquake sequence aftershocks (white bars), from Ratchkovski (2003). Dashed polygons outline inversion blocks for events prior to October 2002. Solid polygons are the inversion regions using the aftershocks. Solid lines are the mapped fault traces. Subevent locations (Eberhart-Phillips et al., 2003) of the $M 7.9$ earthquake are shown as hexagons.

to the west of the Denali-Totschunda branching location, respectively. Best-fitting inversion required a high rupture velocity of about $3.5 \mathrm{~km} / \mathrm{sec}$ between subevents 2 and 3 . Ellsworth et al. (2004) note that the rupture actually went supershear near Trans-Alaska Pipeline Pump Station no. 10 (PS10), whose location is much further to the west of the branching location and is very close to subevent 2 . They also mention that the rupture velocity is about $0.8 c_{s}$ for about $20 \mathrm{~km}$ east of PS10. We therefore carry out our numerical simulations for different values of rupture velocity when approaching the branching location, including supershear rupture velocity. (Rousseau and Rosakis [2003] have extended branching concepts like in Poliakov et al. (2002) to the supershear regime.)

\section{Branching Angle $(\varphi)$}

The Totschunda fault branches away from the Denali fault, to the extensional side, at an angle of approximately $15^{\circ}$. The angle was measured from a fault map of central Alaska provided by Savage and Lisowski (1991).

Wallace et al. (2002) suggested that the northern part of the Totschunda fault system may consist of multiple discontinuous southeast-striking strands and is locally connected by south-striking step-over faults. This may reflect the immaturity of the northern Totschunda system. The aim of our study is to do a first-order analysis of the branching process by simplifying the geometry. This approach to a simpler model is supported by examination of an aerial photo (P. Haeussler, personal comm.) of the branch location, which suggests a simple branching geometry.

\section{Numerical Implementation Using the Boundary Integral Equation (BIE) Method}

Numerical implementation of the dynamic rupture propagation scheme was done using the 2D Boundary Integral Equation (BIE) method as described in Kame et al. (2003). An important advantage of this method is that the domain of calculations is confined to the fault geometry. A longrunning rupture, which is depth limited, as for the DFE event, cannot be modeled in a 2D framework. However, observing the theoretical concepts outlined in Poliakov et al. (2002), Kame et al. (2003), and Rousseau and Rosakis (2003), we can argue that the critical factor, other than the geometry and prestress, is the rupture speed as the branch is approached. This can be suitably simulated in $2 \mathrm{D}$, with far greater grid refinement than in 3D simulations, by nucleating a 2D rupture at various distances from the branching location. Given the present computing capabilities, the 2D formulation allows adequate grid refinement to fully resolve the slipweakening process, a feature which is not generally achieved in 3D simulations. Nevertheless, the rupture phenomenon is clearly a $3 \mathrm{D}$ one, and much has been learned about branching from such simulations by Aochi et al. (2000a,b), Aochi and Fukuyama (2002), Oglesby et al. (2000a,b), and Oglesby and Day (2001).

Following the discretized form of the dynamic representation theorem evaluated by Kame and Yamashita (1999a,b, 2003), we obtain the following algebraic equation for the change in shear traction on spatial cell $l$, at the end of time step $n$, due to the slip history up to that time:

$$
\Delta \tau^{l, n}=\sum_{k=1}^{n} \sum_{i} V^{i, k} K^{l-i, n-k}
$$

where $V^{i, k}$ is the slip velocity of cell $i$, during time step $k$, and $K^{l-i, n-k}$ is the response to unit slip velocity in cell $i$ in time step $k$.

If we now assign the discretization parameters, cell size $\Delta s$ and time step $\Delta t$, such that $c_{p} \Delta t / \Delta s=0.5$, then equation (1) decouples (actually for all $c_{p} \Delta t / \Delta s<1$ ) resulting in an explicit formulation as below ( $c_{p}$ is the $P$-wave speed of the medium):

$$
\Delta \tau^{l, n}=V^{l, n} K^{0,0} \sum_{k=1}^{n-1} \sum_{i} V^{i, k} K^{l-i, n-k}
$$

where $K^{0,0}\left(=-\mu / 2 c_{s}\right)$ is the radiation damping term (Cochard and Madariaga, 1994) for shear modulus $\mu$ and shearwave velocity $c_{s}$. This term represents the instantaneous contribution of the current slip velocity to the shear stress at the same position ( $\mu$ is the shear modulus of the medium and $c_{s}$ is the shear wave speed of the medium). A similar expression applies for the change of normal stress on the fault, except that there is zero instantaneous contribution (Kame et al., 2003). 
We use a slip-weakening friction law as originally proposed by Ida (1972) and Palmer and Rice (1973). We formulate this in a Coulomb manner so that the fault strength is always proportional to the normal stress acting on the fault. Thus, it is the friction coefficient that slip weakens. According to this law, the strength of the fault, at constant compressive normal stress, decreases linearly from an initial peak strength, $\tau_{p}$, to a residual strength, $\tau_{r}$, up to a critical slip, $\Delta u=D_{c}$, and then remains constant at the residual level for any further slip. Thus,

$$
\begin{aligned}
\tau & =\tau_{r}+\left(\tau_{p}-\tau_{r}\right)\left(1-\Delta u / D_{c}\right) H\left(1-\Delta u / D_{c}\right) \\
\tau_{p} & =\mu_{s}\left(-\sigma_{n}\right) ; \quad \tau_{r}=\mu_{d}\left(-\sigma_{n}\right),
\end{aligned}
$$

where $H($.$) is the Heaviside function, \mu_{s}$ and $\mu_{d}$ are the static and dynamic coefficients of friction, respectively; $\left(-\sigma_{n}\right)$ is the normal stress acting on the fault (stress defined as positive in tension). We use the same expression during general stress and slip histories, taking $\tau_{p}$ and $\tau_{r}$ to be proportional to the instantaneous effective normal stress as indicated. Andrews (1976) defined a parameter $S=\left(\tau_{p}-\sigma_{y x}^{0}\right) /$ $\left(\sigma_{y x}^{0}-\tau_{r}\right)$ associated with the slip-weakening law where $\sigma_{y x}^{0}$ is the initial shear stress on the fault. This parameter has a critical value (approximately 1.77 ) below which the rupture propagates with a speed that ultimately transitions to supershear for propagation paths that are sufficiently long compared with the size of the nucleation zone.

All parameters in our calculations are nondimensionalized as follows:

1. Length, $X^{*}=X / R_{0}$

2. Time, $t^{*}=2 c_{p} t / \Delta s$

3. Slip, $\Delta u^{*}=\mu \Delta u /\left[\left(-\sigma_{y y}^{0}\right) R_{0}\right]$

4. Slip velocity $V^{*}=\mu V^{*}=\mu V /\left[\left(-\sigma_{y y}^{0}\right) c_{p}\right]$

5. Stress, $\sigma_{i j}^{*}=\sigma_{i j} /\left(-\sigma_{y y}^{0}\right)$

Here, $-\sigma_{y y}^{0}$ is the initial compressive stress on the primary (Denali) fault, where $R_{0}\left[=(3 \pi / 8)\left(\mu D_{c} /\left(\tau_{p}-\tau_{r}\right)\right)\right]$ is the approximate slip-weakening zone length at low rupture velocity as derived in Palmer and Rice (1973) and Rice (1980) and used in Poliakov et al. (2002) and Kame et al. (2003). The $P$-wave speed of the medium is $c_{p}$ and $\mu$ is the shear modulus. To fully resolve the slip-weakening process, $\Delta s$ should be much less than $R_{0}$. We use $R_{0} / \Delta s=5$ or 10 in our simulations, the larger number being needed when rupture propagation speed is close to the Rayleigh speed $\left(\approx 0.92 c_{s}\right)$.

The numerical simulation of dynamic-rupture propagation is carried out in the following two steps.

Static Slip Distribution along the Minimum Nucleation Length. To obtain the required rupture velocity on the primary fault at the branching location, we nucleate the rupture at various distances from the branching location without referring to the actual nucleation point on the Denali fault. Our goal here is to understand the dynamics of the rupture front at various speeds as the branch is approached and not to simulate the entire event (impossible within our 2D formulation).

The minimum nucleation length $\left(L_{c}\right)$, as described in Andrews (1976) and Kame et al. (2003), obtained from the fracture mechanics energy balance (for Poisson ratio $v=$ 0.25 ) is determined using

$$
L_{c}=\frac{16}{3 \pi} \frac{\mu G}{\left(\sigma_{y x}^{0}-\tau_{r}\right)^{2}}=\frac{64}{9 \pi^{2}}\left(\frac{\tau_{p}-\tau_{r}}{\sigma_{y x}^{0}-\tau_{r}}\right)^{2} R_{0},
$$

where $L_{c}$ is the total length of the slipping zone (twice the length in Andrews [1976]). We choose a certain length of the fault, $L$, such that $L / R_{0}$ is slightly greater than $L_{c} / R_{0}$. In this region we prescribe a slip distribution and prevent any slip outside the region, such that the fault is in static equilibrium. This causes an initial stress concentration that is slightly larger than the peak strength at both ends of the static nucleation zone and finitely accelerates rupture in the first dynamic time steps (Kame et al., 2003).

Dynamic Rupture Propagation. After prescribing the slip distribution as explained in the previous step, the rupture is allowed to propagate dynamically along the main fault and the rupture-velocity history is calculated to position a branch to the primary fault so that the rupture velocity on the primary fault, when approaching the branch, is the one desired.

The branch is placed in position and dynamic rupture is then allowed to continue both along the main and the branched faults. We monitor stress in each time step to see whether rupture begins $\left(\tau \geq-\mu_{s} \sigma_{n}\right.$ ) at the first element of the branch and at the front of any rupture along it and the main fault.

\section{Summary of Results}

Numerical studies were conducted by using the boundary integral equation method elaborated earlier. Figure 6 shows the fault geometry adopted for our simulations, of which preliminary results were reported in Bhat et al. (2002).

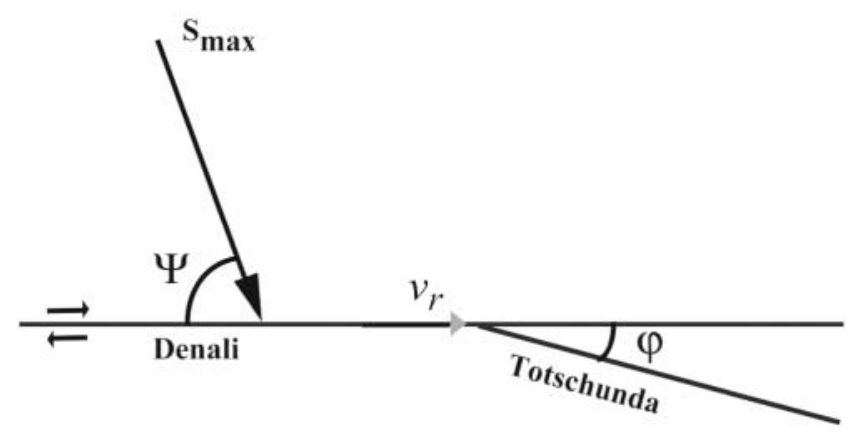

Figure 6. Fault geometry used in the model along with the associated parameters. 
Because the $S$ ratio governs the nature of rupture (supershear or subshear), a desired value is first chosen. This would then give the initial shear stress acting on the fault (as a fraction of $-\sigma_{y y}^{0}$ ) if values of $\mu_{s}$ and $\mu_{d}$ are assumed. If the prestress field is normalized by the fault normal prestress, then the normalized fault parallel prestress can be obtained by using the desired value of $\Psi$, the orientation of the principal maximum compressive stress with the primary fault. The prestress parameters thus obtained must be checked so that the Mohr-Coulomb failure criterion based on $\mu_{s}$ is not violated either on the primary or the branched fault.

Dreger et al. (2004) noted, in their dynamic source modeling of the DFE using a 3D finite element method, that the rupture actually jumps ahead of the primary rupture front by $14 \mathrm{~km}$, triggering slip on the Totschunda fault. We do not observe such a phenomenon in our simulations.

Our calculations were done for various values of $v_{r}$ and $\Psi$ at the Denali-Totschunda branching location.

Case 1: $v_{r}=0.60 c_{s} ; \Psi=70^{\circ} ; \mu_{s}=0.60$;

$\mu_{d}=0.12 ; S_{\text {Den }}=3 ; S_{\text {Tot }}=0.6$

When the velocity of the rupture approaching the branching location at the Totschunda fault is $0.6 c_{s}$, the rupture branches completely onto the Totschunda fault. Figure 7 shows the combined plots of slip velocity along both the
Denali and Totschunda faults. It is clearly observed that once the rupture on the Denali fault crosses the branching location the slip velocity decreases rapidly with time. This is a clear indication of that the main fault can no longer accommodate slip beyond the branching location.

At time step 365 the rupture has reached the branching point. We observe in our simulations at this time step that the slip velocity at the right end of the rupture front accelerates briefly before slowing down. This may be a result of numerical oscillations in our calculations.

Case 2: $v_{r}=0.80 c_{s} ; \Psi=70^{\circ} ; \mu_{s}=0.60$;

$\mu_{d}=0.12 ; S_{\text {Den }}=3 ; S_{\text {Tot }}=0.6$

For this case, the rupture again branches along the Totschunda fault with no further continuation on the Denali fault. Figure 8 shows slip velocity along both the Denali and Totschunda faults. It is clear, as in the previous case, that beyond the branch, the slip velocity diminishes rapidly on the Denali fault.

Case 3: $v_{r}=0.90 c_{s} ; \Psi=70^{\circ} ; \mu_{s}=0.60$;

$\mu_{d}=0.12 ; S_{\text {Den }}=3 ; S_{\text {Tot }}=0.6$

Earlier studies by Kame et al., (2003) showed that, for this value of rupture velocity and for $\Psi=56^{\circ}$, the rupture
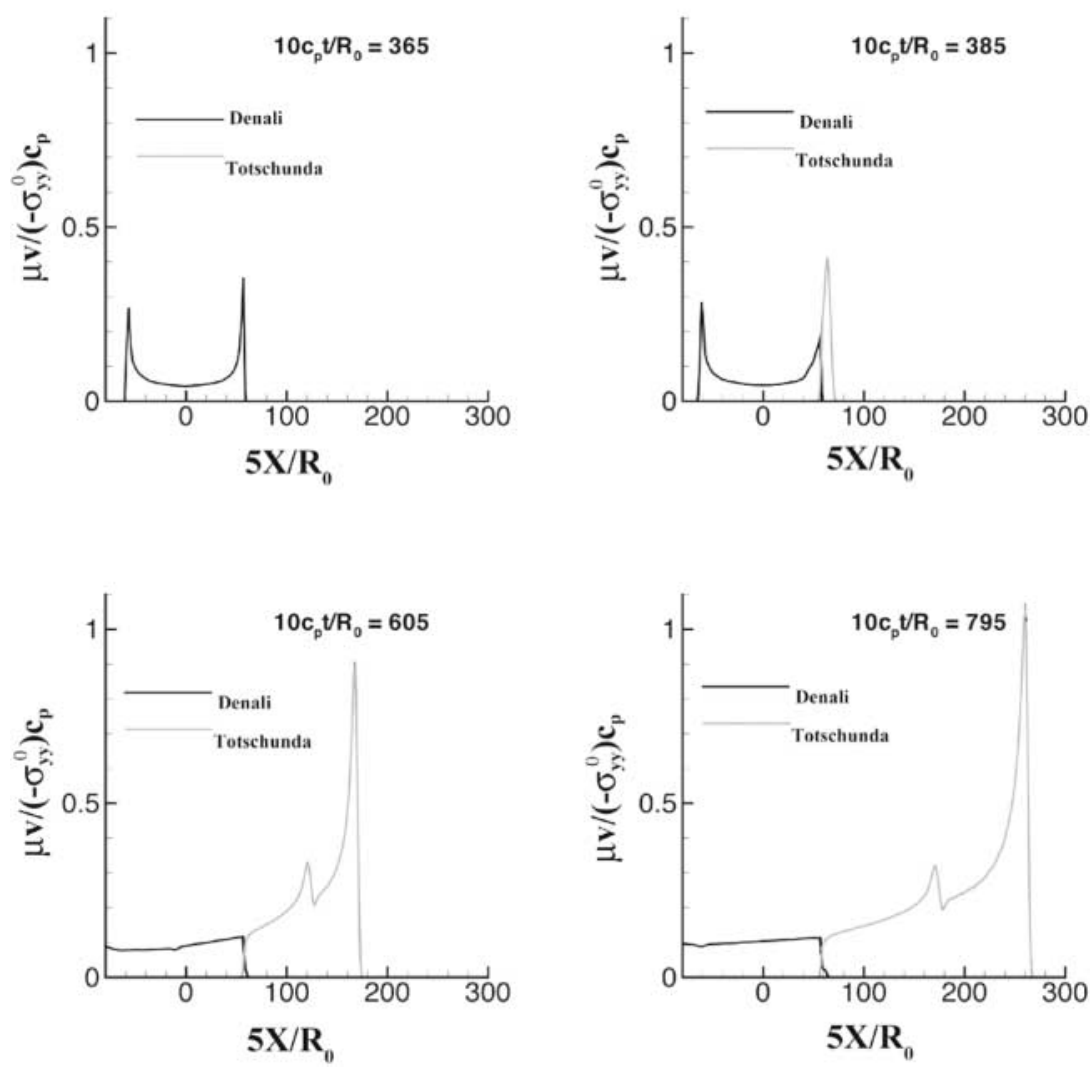

Figure 7. Plot of slip velocity along the Denali and Totschunda fault segments for $\Psi=$ $70^{\circ} ; v_{r}=0.6 c_{s}$. Slip velocity variation along the Totschunda fault is projected onto the Denali fault. The Totschunda fault begins at $5 X / R_{0}$ $=58 . v_{r}, c_{s}, R_{0}, \mu, v,-\sigma_{y y}^{0}$, and $c_{p}$ represent the rupture velocity near the branching point, the $S$-wave speed of the medium, the size of the slip-weakening zone, the shear modulus of the medium, the slip velocity, the initial normal compressive stress, and the $P$-wave velocity of the medium, respectively. 


$$
\Psi=70^{\circ}, v_{r}=0.8 c_{s}, \varphi=-15^{0}
$$
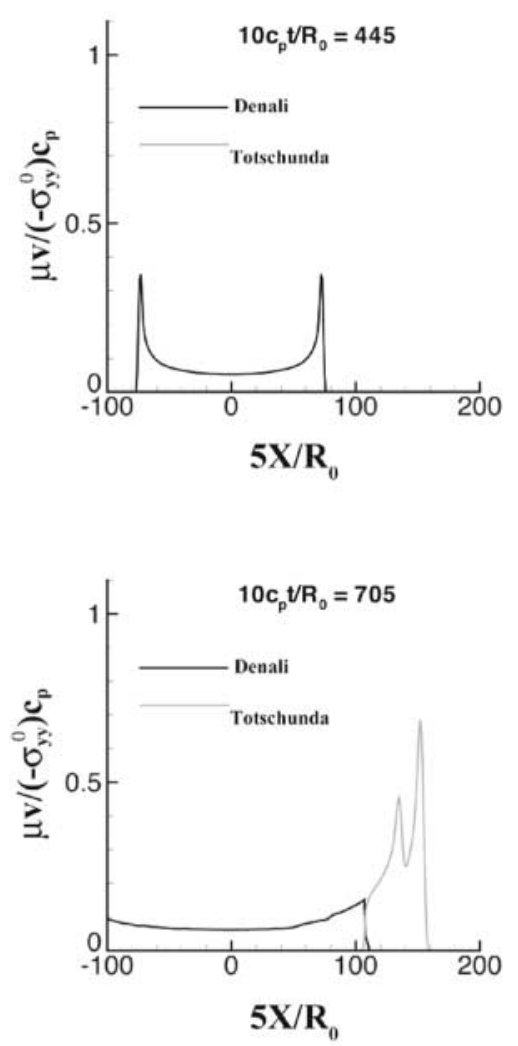
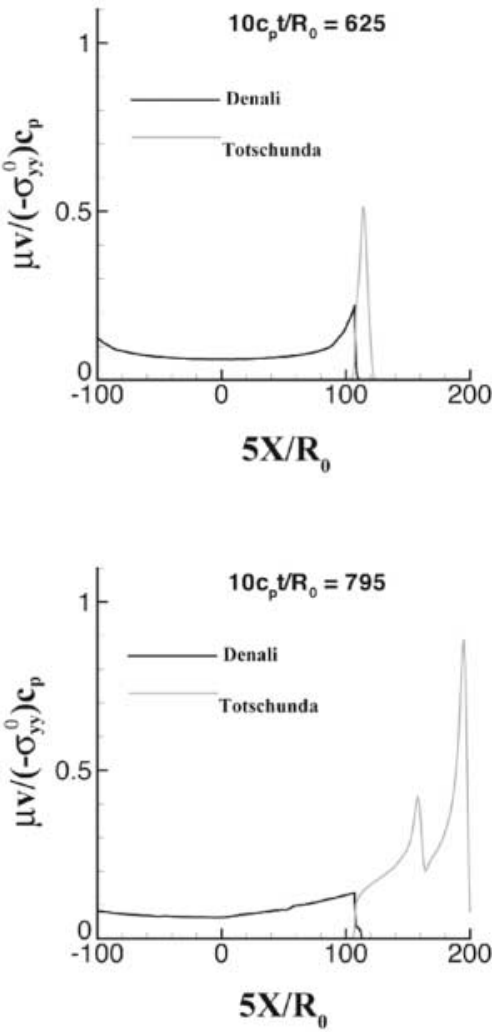

Figure 8. Slip velocity along the Denali and Totschunda fault segments for $\Psi=70^{\circ}$; $v_{r}=0.8 c_{s}$. Slip-velocity variation along the Totschunda fault is projected on the Denali fault. Totschunda fault begins at $5 X / R_{0}=108$. tends to propagate both along the main and the branched fault in the extensional side with a small branching angle of $15^{\circ}$. The same happens in this case with $\Psi=70^{\circ}$ but not, as we shall see next, when $\Psi=80^{\circ}$. Figure 9 shows the variation of slip velocity along the Denali and Totschunda faults. As can be seen in this figure, the slip velocity on the Denali fault beyond the Totschunda fault is significant, resulting in simultaneous propagation of rupture along both faults beyond the branching location, albeit at a slower rate and with less slip on the Denali fault than on the Totschunda fault.

Case 4: $v_{r}=0.87 c_{s} ; \Psi=80^{\circ} ; \mu_{s}=0.40$;

$\mu_{d}=0.05 ; S_{\text {Den }}=4 ; S_{\text {Tot }}=0.4$

As stated earlier, the likelihood of the rupture propagating exclusively along the extensional branch increases with increasing inclination of $\Psi$. In this case, we increase $\Psi$ to $80^{\circ}$ and maintain the rupture velocity at $0.87 c_{s}$ while approaching the Totschunda fault. In this model, we changed the friction coefficients because with the earlier values of friction coefficients the prestress field violated the MohrCoulomb failure criterion outside the fault zones.

Our results show that, for the case 4 , the rupture proceeds rapidly along the Totschunda fault with almost no con- tinuation on the Denali fault. Figure 10 shows slip velocity along both the Denali and Totschunda faults. Again, beyond the Totschunda fault, the slip velocity diminishes quickly on the Denali fault. There is some continuation of rupture on the Denali fault beyond the Totschunda fault, although this length is of the order of $R_{0}$, the size of the slip-weakening zone. This is negligible in comparison with the progress of rupture on the Totschunda fault. Hence, we can conclude here that the rupture takes the Totschunda fault exclusively.

Case 5: $v_{r}=1.40 c_{s} ; \Psi=70^{\circ} ; \mu_{s}=0.50 ;$
$\mu_{d}=0.10 ; S_{\text {Den }}=1 ; S_{\text {Tot }}=0.09$

Although we have no reason at present to think that the rupture velocity was supershear near the branch junction, we also performed a simulation in which the rupture velocity when approaching the Denali-Totschunda branching location was $1.40 c_{s}$. To make an appropriate choice for the $S$ ratio so that the rupture velocity was supershear and the Mohr-Coulomb failure criteria were not violated by the prestress field, we were required to choose these values for dynamic and static coefficients of friction.

Slip velocity (Fig. 11) on the Denali and Totschunda faults shows that on the part of the Denali fault beyond the 


$$
\Psi=70^{\circ}, v_{r}=0.9 c_{s}, \varphi=-15^{0}
$$
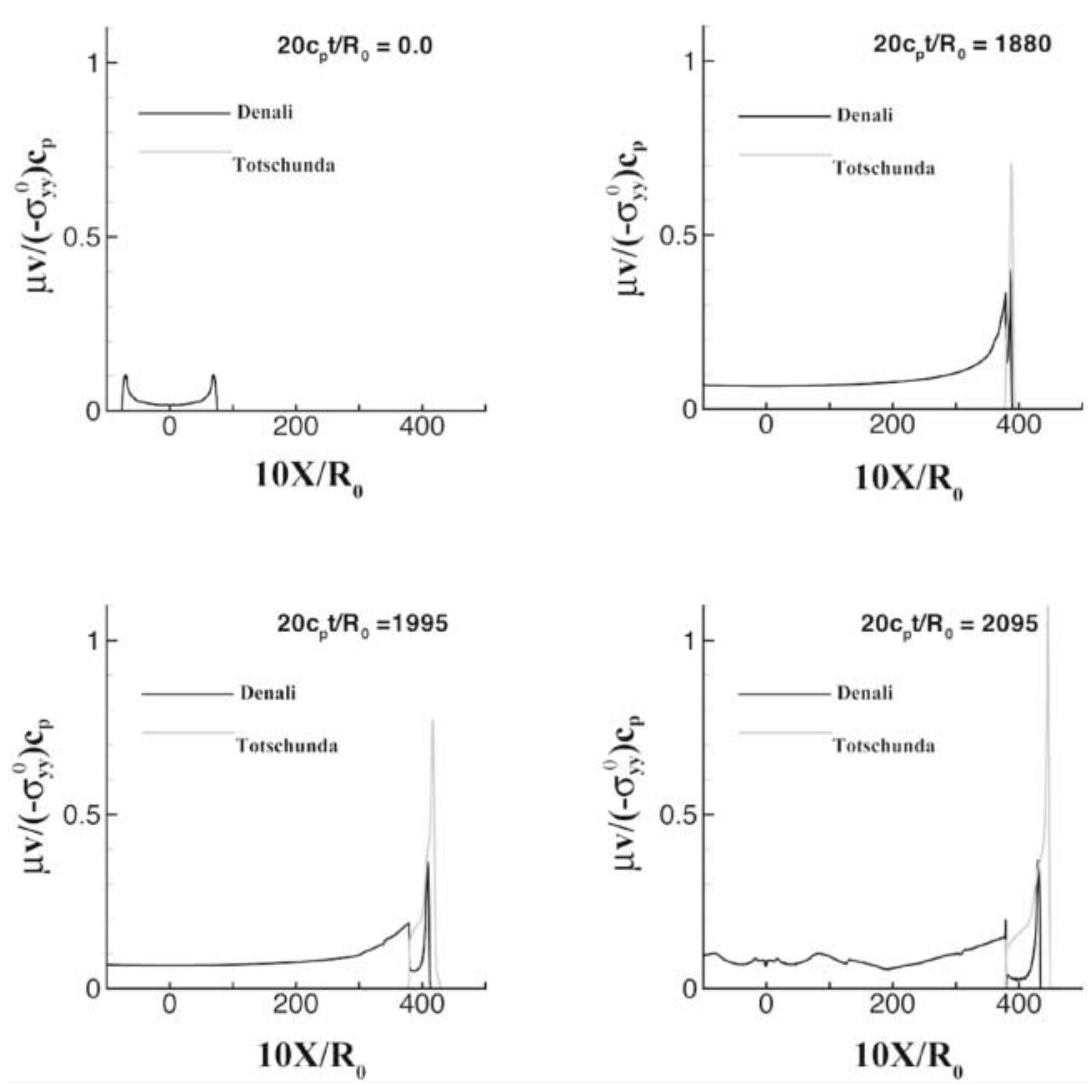

Figure 9. Slip velocity along the Denali and Totschunda fault segments for $\Psi=70^{\circ}$; $v_{r}=0.9 c_{s}$. Slip-velocity variation along the Totschunda fault is projected onto the Denali fault. The Totschunda fault begins at $10 X / R_{0}$ $=380$. junction, the slip velocity decays rapidly, suggesting that segment of the Denali fault beyond the Totschunda intersection will ultimately stop slipping. On the Totschunda fault the speed briefly reduced to sub-Rayleigh then went supershear again, exhibiting a pattern similar to those observed in other cases of sub-Rayleigh to supershear transitions, leaving pulses that move as Rayleigh waves on what was the crack surface before the intersonic transition and provide a multipulse character to the slip-rate distribution.

\section{Summary and Conclusions}

The theory of fault branching developed by Poliakov et al. (2002) and Kame et al. (2003) was tested on the recent Denali fault earthquake using the numerical method developed by Kame et al. (2003). The theoretical stress analysis of a propagating mode II rupture suggests that the tendency to follow a branch is influenced by rupture velocity $v_{r}$ approaching the branch, preexisting maximum compressive stress inclination $\Psi$, and prospective branching angle $\varphi$. This study provides another comparison of the rules of branching with a field case; five other such field cases were discussed by Kame et al. (2003).
We numerically simulated the observed slip transfer from the Denali to Totschunda faults by the methodology of Kame et al. (2003), which uses a 2D elastodynamic boundary integral equation model of mode II rupture with selfchosen path along a branched fault system. The strength of the faults was assumed to follow a Coulomb law with a friction coefficient that slip-weakens from its static to dynamic value. Figure 12 shows the rupture velocity variation on the Denali and Totschunda faults for cases $\Psi=70^{\circ}$; $v_{r}=0.6 c_{s}$ and $\Psi=70^{\circ} ; v_{r}=0.9 c_{s}$, respectively. The rupture velocity on the Totschunda fault beyond the branching location for the case $\Psi=70^{\circ} ; v_{r}=0.9 c_{s}$ remains steady at a value of $1.1 c_{s}$, a value that falls within the range for unstable dynamic rupture propagation on a single fault (Freund, 1979); the speed may be, stabilized by the existence of the neighboring rupture propagating along the Denali fault. All but one of our simulations for incoming subRayleigh rupture velocities predict that the rupture path will branch off along the Totschunda fault without continuation along the Denali fault. The exception is the case when the prestress inclination is $70^{\circ}$, a lower limit to the plausible range, and incoming rupture speed at the branching point is $0.9 c_{s}$. In this case rupture follows the branch, but rupture 


$$
\Psi=80^{\circ}, v_{r}=0.87 c_{s}, \varphi=-15^{\circ}
$$
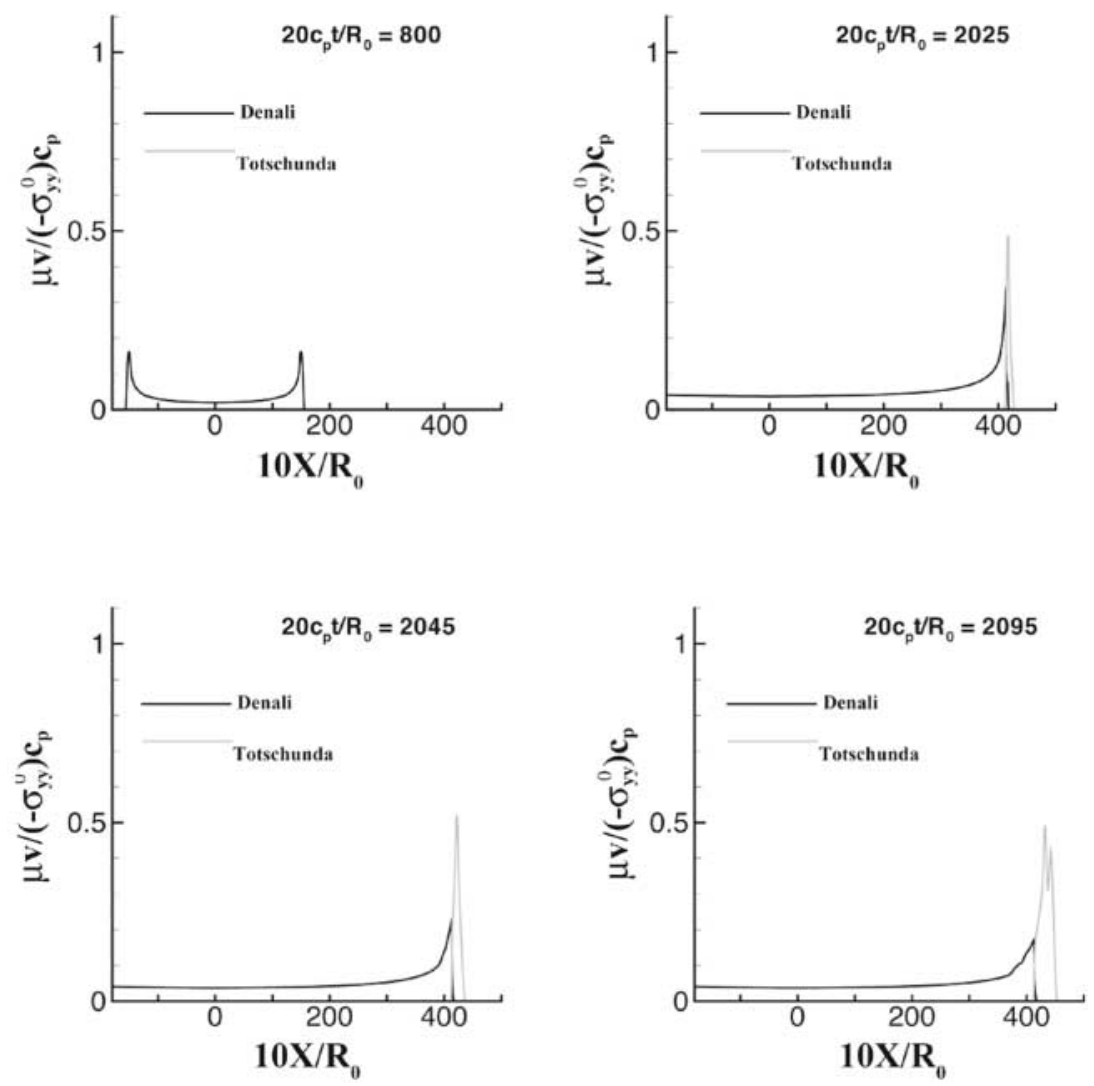

Figure 10. Slip velocity along the Denali and Totschunda fault segments for $\Psi=80^{\circ}$; $v_{r}=0.87 c_{s}$ case. Slip velocity variation along the Totschunda fault is projected onto the Denali fault. The Totschunda fault begins at $10 X /$ $R_{0}=414$. also continues along the Denali fault beyond the branching location, at a lower speed than that along the Totschunda fault. However, when the prestress inclination is steeper, at $80^{\circ}$, the rupture chooses Totschunda exclusively when its velocity near the branching location is about $0.9 c_{s}$. We also see exclusive continuation of rupture on the Totschunda fault when the rupture is supershear, $1.4 c_{s}$.

\section{Acknowledgments}

Our studies were funded by Earth Sciences Research at the National Science Foundation (NSF-EAR) Grant 0105344 to Harvard University on "Rupture propagation and arrest in geometrically complex fault systems: Bends, stepovers, and damaged border zones." In addition, N. K. was supported by Ministry of Education, Culture, Sports, and Technology (MEXT) Grant-in-Aid for Young Scientists (B) 15740277 and RR2003 MEXT grant on "Regional characterization of the crust in metropolitan areas for the prediction of strong ground motion." We thank Peter Haeussler, Bill Ellsworth, and Natasha Ratchkovski for supplying their research results to us prior to publication and David Oglesby for many enlightening discussions.

\section{References}

Andrews, D. J. (1976). Rupture velocity of plane strain shear cracks, $J$. Geophys. Res. 81, 5679-5687.

Aochi, H., and E. Fukuyama (2002). Three-dimensional non-planar simu- lation of the 1992 Landers earthquake, J. Geophys. Res. 107, 2035, doi 10.1029/2000JB000061, pp. ESE 4-1 to 4-12.

Aochi, H., E. Fukuyama, and M. Matsu'ura (2000a). Spontaneous rupture propagation on a non-planar fault in 3D elastic medium, Pure Appl. Geophys. 157, 2003-2027.

Aochi, H., E. Fukuyama, and M. Matsu'ura (2000b). Selectivity of spontaneous rupture propagation on a branched fault, Geophys. Res. Lett. 27, 3635-3638.

Bhat, H., R. Dmowska, J. R. Rice, and N. Kame (2002). Testing theory for fault branching: Denali to Totschunda, Alaska, November 3, 2002 (abstract), Trans. Am. Geophys. U., EOS 83, S72F-1364.

Cochard, A., and R. Madariaga (1994). Dynamic faulting under rate dependent friction, Pure Appl. Geophys. 142, 419-445.

Dreger, D. S., D. D. Oglesby, R. Harris, N. Ratchkovski, and R. Hansen (2004). Kinematic and Dynamic rupture models of the November 3, 2002, $\mathrm{M}_{\mathrm{w}}$ 7.9 Denali, Alaska, earthquake, Geophys. Res. Lett. 31, L04605, doi 10.1029/2003GL018333.

Eberhart-Phillips, D., P. J. Haeussler, J. T. Freymueller, A. D. Frankel, C. M. Rubin, P. Craw, N. A. Ratchkovski, G. Anderson, G. A. Carver, A. J. Crone, T. E. Dawson, H. Fletcher, R. Hansen, E. L. Harp, R. A. Harris, D. P. Hill, S. Hreinsdóttir, R. W. Jibson, L. M. Jones, R. Kayen, D. K. Keefer, C. F. Larsen, S. C. Moran, S. F. Personius, G. Plafker, B. Sherrod, K. Sieh, N. Sitar, and W. K. Wallace (2003). The 2002 Denali fault earthquake, Alaska: a large magnitude, slippartitioned event, Science 300, 1113-1118.

Ellsworth, W. L., M. Çelebi, J. R. Evans, E. G. Jensen, D. J. Nyman, and P. Spudich (2004). Processing and modeling of the pump station 10 record from the November 3, 2002, Denali fault, Alaska earthquake, 


$$
\Psi=70^{\circ}, v_{r}=1.4 c_{s}, \varphi=-15^{0}
$$
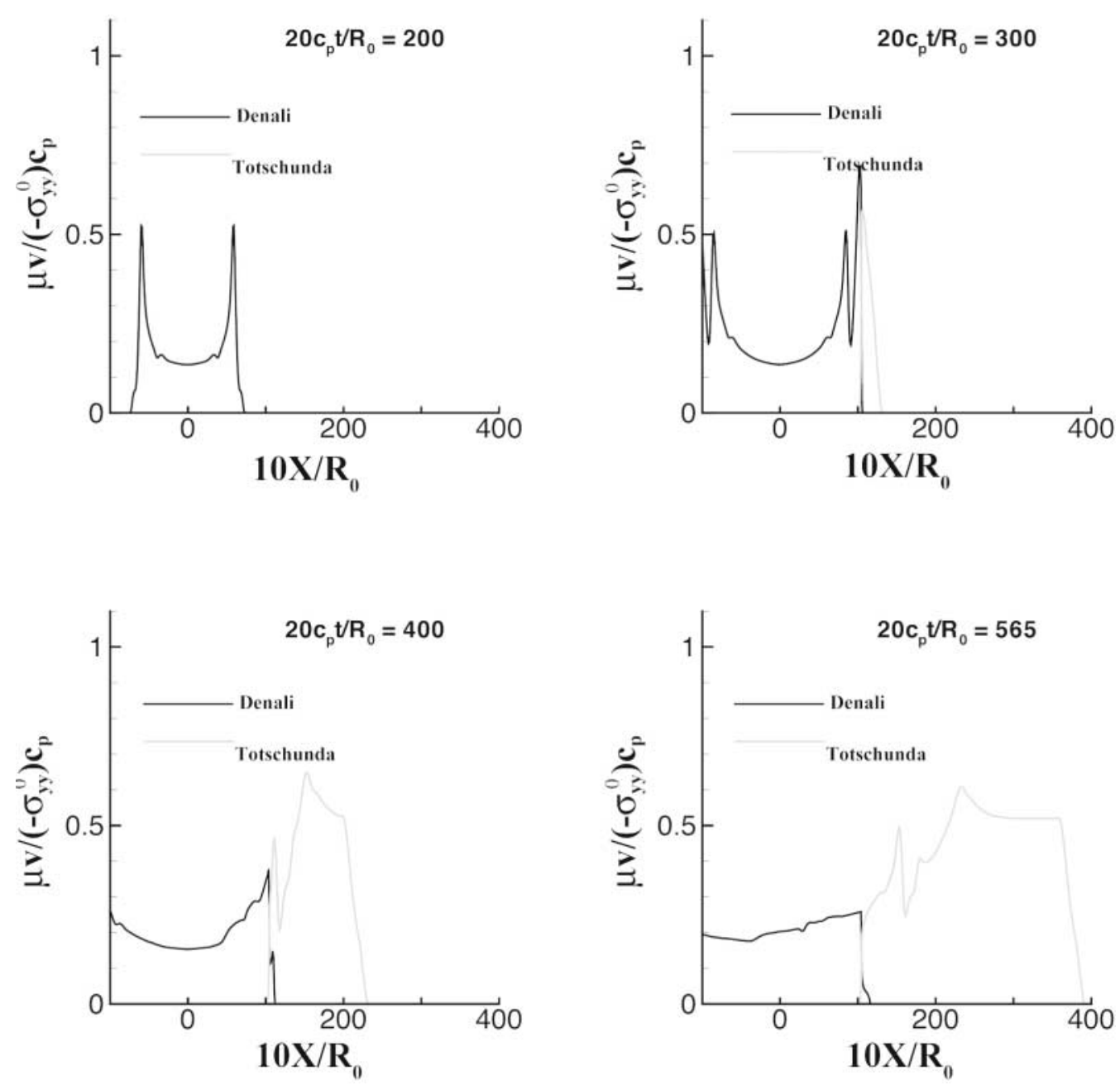

Figure 11. Slip velocity along the Denali and Totschunda fault segments for $\Psi=$ $70^{\circ} ; v_{r}=1.4 c_{s}$. Slip-velocity variation along the Totschunda fault is projected onto the Denali fault. The Totschunda fault begins at $10 X / R_{0}=104$.

11th International Conference On Soil Dynamics \& Earthquake Engineering, Berkeley, California, 471-477.

Estabrook, C. H., and K. H. Jacob (1991). Stress indicators in Alaska, in Neotectonics of North America, D. B. Slemmons, E. R. Engdahl, M. D. Zoback, and D. D. Blackwell (Editors), Geological Society of America, Boulder, Colorado, Decade Map vol. 1, 387-399.

Estabrook, C. H., D. B. Stone, and J. N. Davies (1988). Seismotectonics of northern Alaska, J. Geophys. Res. 93, 12,026-12,040.

Freund, L. B. (1979). The mechanics of dynamic shear crack propagation, J. Geophys. Res. 84, 2199-2209.

Ida, Y. (1972). Cohesive force across the tip of a longitudinal-shear crack and Griffth's specific surface energy, J. Geophys. Res. 77, 3796-3805.

Kame, N., and T. Yamashita (1999a). A new light on arresting mechanism of dynamic earthquake faulting, Geophys. Res. Lett. 26, 1997-2000.

Kame, N., and T. Yamashita (1999b). Simulation of spontaneous growth of dynamic crack without constraints on the crack tip path, Geophys. J. Int. 139, 345-358.
Kame, N., and T. Yamashita (2003). Dynamic branching, arresting of rupture and the seismic wave radiation in self-chosen crack path modeling, Geophys. J. Int. 155, 1042-1050.

Kame, N., J. R. Rice, and R. Dmowska (2003). Effects of pre-stress state and rupture velocity on dynamic fault branching, J. Geophys. Res. 108, 2265, doi 10.1029/2002JB002189, pp. ESE 13-1 to 13-21.

Kikuchi, M., and Y. Yamanaka (2002). Source rupture processes of the central Alaska earthquake of Nov. 3, 2002, inferred from teleseismic body waves (the 10/23 M6.7 event), EIC Seismological Note No. 129, revised 5 November 2002. Available from the Earthquake Information Center, University of Tokyo, at www.eic.eri.u-tokyo.ac.jp/EIC/ EIC_News/021103AL-e.html.

Nakamura, K., G. Plafker, K. H. Jacob, and J. N. Davies (1980). A tectonic stress trajectory map of Alaska using information from volcanoes and faults, Bull. Earthquake Res. Inst. 55, 89-100.

Oglesby, D. D., and S. M. Day (2001). The effect of fault geometry on the 


$$
\Psi=70^{\circ}, v_{r}=0.6 c_{s}, \varphi=-15^{0}
$$
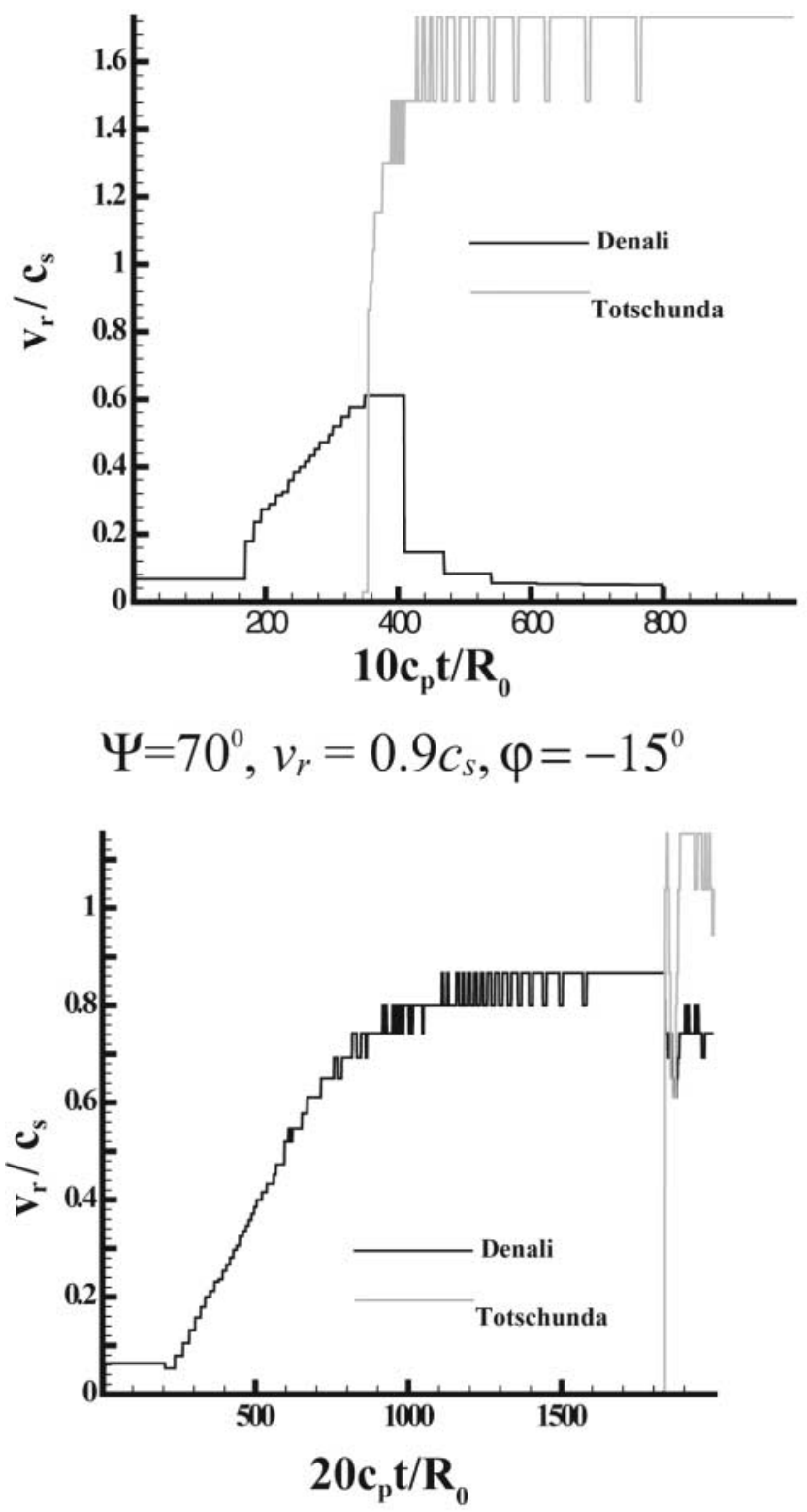

Figure 12. Variation of the rupture velocity along the Denali and the Totschunda fault segments for $\Psi$ $=70^{\circ} ; v_{r}=0.6 c_{s}$ and $\Psi=70^{\circ} ; v_{r}=0.9 c_{s}$ cases. $v_{r}, c_{s}, R_{0}$, and $c_{p}$ represent the rupture velocity near the branching point, the $S$-wave speed of the medium, the size of the slip-weakening zone, and the $P$-wave velocity of the medium, respectively. The rupture velocity is determined using the time required to advance three spatial cells, hence possible values of the rupture velocity are quantized.
1999 Chi-Chi (Taiwan) earthquake, Geophys. Res. Lett. 28, 18311834.

Oglesby, D. D., R. J. Archuleta, and S. B. Nielsen (2000a). The threedimensional dynamics of dipping faults, Bull. Seism. Soc. Am. 90, 616-628.

Oglesby, D. D., R. J. Archuleta, and S. B. Nielsen (2000b). Dynamics of dip-slip faulting: Explorations in two dimensions, J. Geophys. Res. 105, 13,643-13,653.

Palmer, A. C., and J. R. Rice (1973). The growth of slip surfaces in the progressive failure of over-consolidated clay, Proc. R. Soc. London A 332, 527-548

Poliakov, A. N. B., R. Dmowska, and J. R. Rice (2002). Dynamic shear rupture interactions with fault bends and off-axis secondary faulting, J. Geophys. Res. 107, 2295, doi 10.1029/2001JB000572, pp. ESE 61 to $6-18$.

Ratchkovski, N. A. (2003). Change in stress directions along the central Denali fault, Alaska after the 2002 earthquake sequence, Geophys. Res. Lett. 30, 2017, doi 10.1029/2003GL017905.

Ratchkovski, N. A., and R. A. Hansen (2002). New constraints on tectonics of interior Alaska: Earthquake locations, source mechanisms, and stress regime, Bull. Seism. Soc. Am. 92, 998-1014.

Rice, J. R. (1980). The mechanics of earthquake rupture, in Physics of the Earth's Interior (Proc. Int'l. School of Physics 'Enrico Fermi', Course 78, pp. 555-649, 1979), A. M. Dziewonski and E. Boschi (Editors), Italian Physical Society and North-Holland Publishing Co., Amsterdam.

Rousseau, C.-E., and A. J. Rosakis (2003). On the influence of fault bends on the growth of sub-Rayleigh and intersonic dynamic shear ruptures, J. Geophys. Res. 108, 2411, doi 10.1029/2002JB002310.

Savage, J. C., and M. Lisowski (1991). Strain accumulation along the Denali fault at the Nenena river and Delta river crossings, Alaska, J. Geophys. Res. 96, 14,481-14,492.

Wallace, W. K., Sherrod, B. L., and T. E. Dawson (2002). Character and significance of surface rupture near the intersection of the Denali and Totschunda faults, M7.9 Denali fault earthquake, Alaska, November 3, 2002 (abstract). EOS 83, S72F-1335.

Harvard University

Division of Engineering and Applied Sciences

29 Oxford Street

Cambridge, Massachusetts 02138

bhat@esag.harvard.edu

(H.S.B.)

Harvard University

Division of Engineering and Applied Sciences and Department of Earth and Planetary Sciences

29 Oxford Street

Cambridge, Massachusetts 02138

(R.D.)

Harvard University

Division of Engineering and Applied Sciences and

Department of Earth and Planetary Sciences

29 Oxford Street

Cambridge, Massachusetts 02138

(J.R.R.)

Kyushu University

Department of Earth and Planetary Sciences

Faculty of Sciences

6-10-1 Hakozaki

Higashi-ku

Fukuoka 812-8581

Japan

(N.K.) 